\title{
Triptycene quinones in synthesis: preparation of triptycene bis-cyclopentenedione
}

\author{
Spyros Spyroudis* and Nikoletta Xanthopoulou \\ Laboratory of Organic Chemistry, Department of Chemistry,University of Thessaloniki, \\ Thessaloniki 54124, Greece \\ E-mail: sspyr@chem.auth.gr
}

Dedicated to Professor Anastasios Varvoglis on his $65^{\text {th }}$ birthday

(received 23 Dec 02; accepted 28 Mar 03; published on the web 06 May 03)

\begin{abstract}
The preparation of triptycene bis-quinone 2 starting from a Diels-Alder reaction of 1,4dimethoxyanthracene and p-benzoquinone is described. This compound was transformed to triptycene bis-cyclopentenedione $\mathbf{1 6}$ through a double hydroxyquinone - iodonium ylide formation- ring contraction sequence.
\end{abstract}

Keywords: Triptycene, quinones, cyclopentenediones, phenyliodonium

\section{Introduction}

Triptycene quinones are triptycene derivatives in which at least one benzo group has been replaced by a quinonoid ring. Some representative structures of triptycene quinones are shown in Figure 1 below.

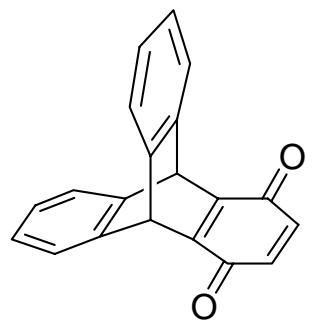

triptycene quinone, 1

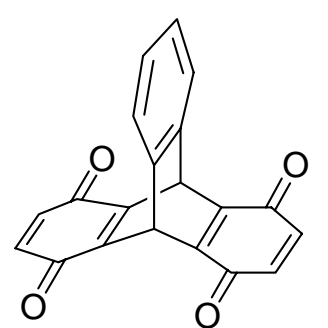

triptycene bis-quinone, 2

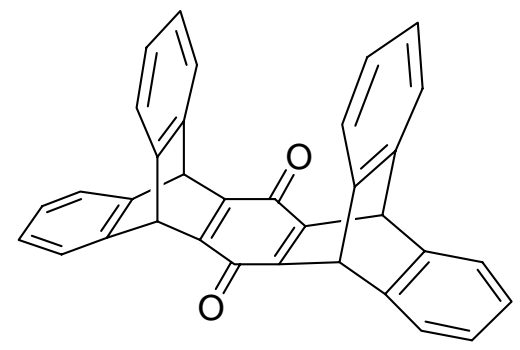

pentiptycene quinone, 3

Figure 1. Structures of triptycene quinones. 
Such compounds combining the rigid structure of triptycene with the redox potential of quinones find several applications in Chemistry. Triptycene quinones serve as building blocks for the construction of three-dimensional supramolecules ${ }^{1}$ and liquid crystalline derivatives, ${ }^{2}$ for the synthesis of electron-transfer compounds with porphyrins ${ }^{3}$ and tetrathiafulavalene ${ }^{4}$ serving as donors, and for the preparation of polymeric chemosensors. ${ }^{5}$ More recently pentiptycene quinones of type 3 were reported to form materials with monolayer assembly structure, ${ }^{6}$ to find application as fluorescent chemosensors for metal ions, ${ }^{7}$ and serve as building blocks for the construction of novel chain and channel networks. ${ }^{8}$

Triptycene quinones exhibit also interesting biological activity: a variety of them decrease the viability of leukemic cells in vitro, ${ }^{9}$ triptycene quinones with methoxy substituents exhibit antioxidant and anti-inflammatory properties, ${ }^{10}$ while the reaction of triptycene diquinones with amines was reported to afford derivatives with potent anticancer and antimalarial activities. ${ }^{11}$

In relation to our interest in hydroxyquinones ${ }^{12}$ we recently reported ${ }^{13}$ the synthesis of triptycene hydroxyquinone 3 and its conversion through phenyliodonium chemistry to triptycene cyclopentenedione, 5 . The latter reacts as a dienophile and dipolarophile affording polycyclic adducts 6 bearing the triptycene moiety (Scheme 1).

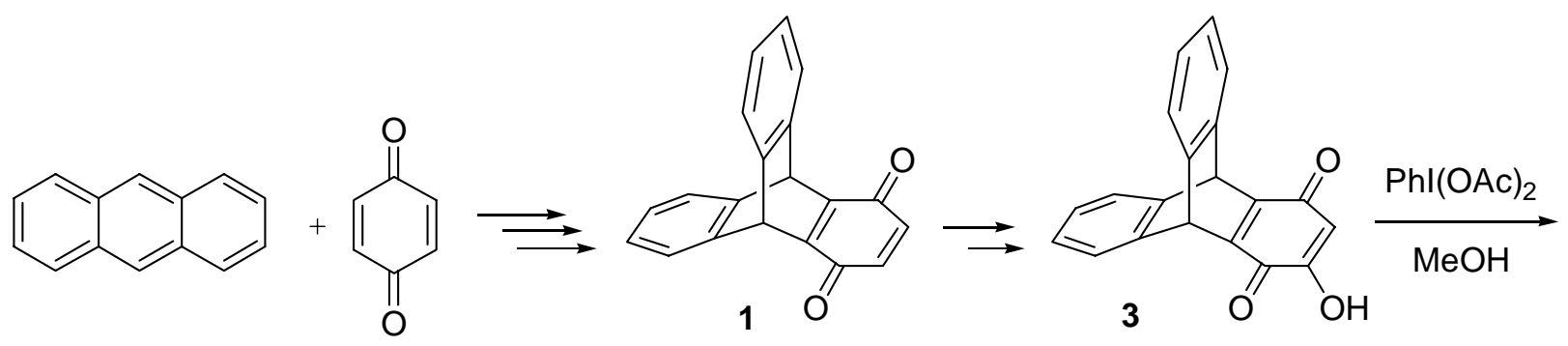

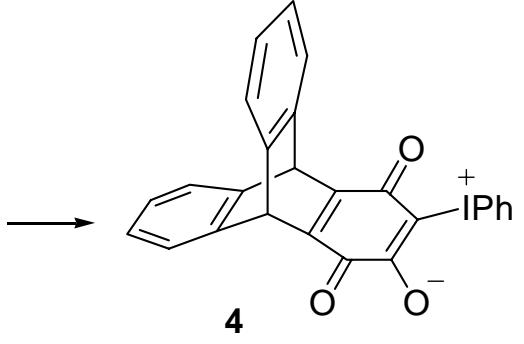

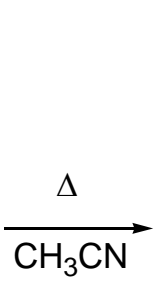

$\Delta$

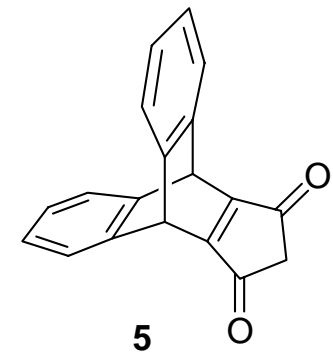

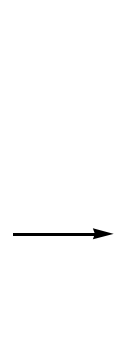

Scheme 1. Preparation of triptycene cyclopentenedione 5.

The successful preparation of 5 prompted us to investigate the possibility of preparing the triptycene bis-cyclopentenedione $\mathbf{1 6}$ by applying the same methodology. We herein wish to report the results of our efforts. 


\section{Results and Discussion}

The synthesis of $\mathbf{1 6}$ was based on the retrosynthetic route shown in Scheme 2, having as key steps the preparation of triptycene dihydroxy-bis-quinones 13 and hence bis-quinone 2, which was reported in the literature albeit without experimental details for its preparation. ${ }^{14}$
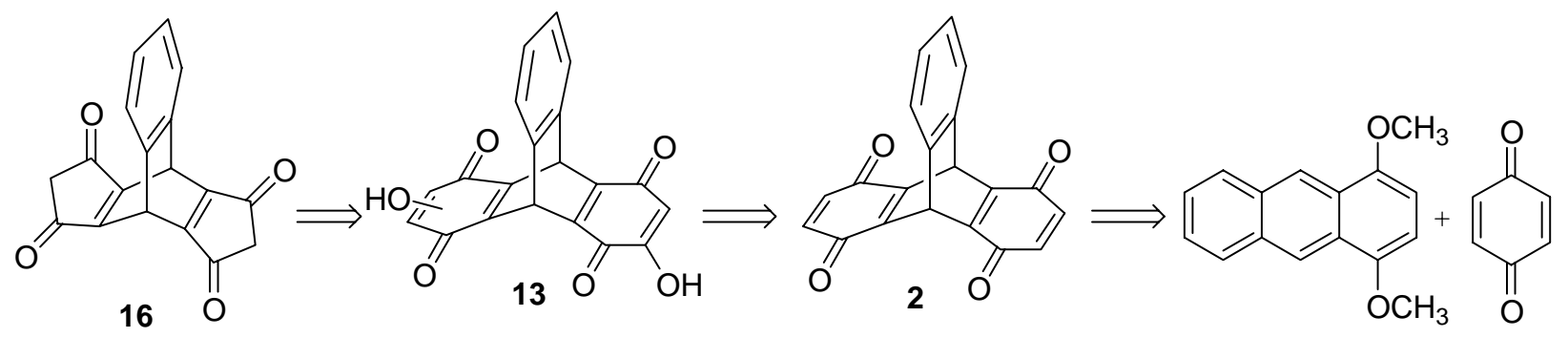

Scheme 2. Retrosynthetic route to triptycene bis cyclopentenedione $\mathbf{1 6 .}$

Triptycene bis-quinone 2 was prepared in three steps starting with a Diels-Alder reaction of 1,4-dimethoxyanthracene and 1,4-benzoquinone. The former is not commercially available and was prepared from quinizarin also in three steps (methylation and two subsequent reductions with $\mathrm{NaBH}_{4}$ ) following a literature method. ${ }^{15}$ The Diels- Alder reaction did not work well in the solvents usually used for cyclization (toluene or xylene) but in refluxing acetonitrile the dehydro adduct 7 was isolated in reasonable yield. This adduct was acid-isomerised almost quantitatively to the corresponding hydroquinone derivative $\mathbf{8}$ which was effectively oxidized by (diacetoxyiodo) benzene to dimethoxy triptycene quinone 9. Finally, 9 was oxidativelydemethylated by ceric ammonium nitrate (CAN) to the desired bis-quinone 2 (Scheme 3).
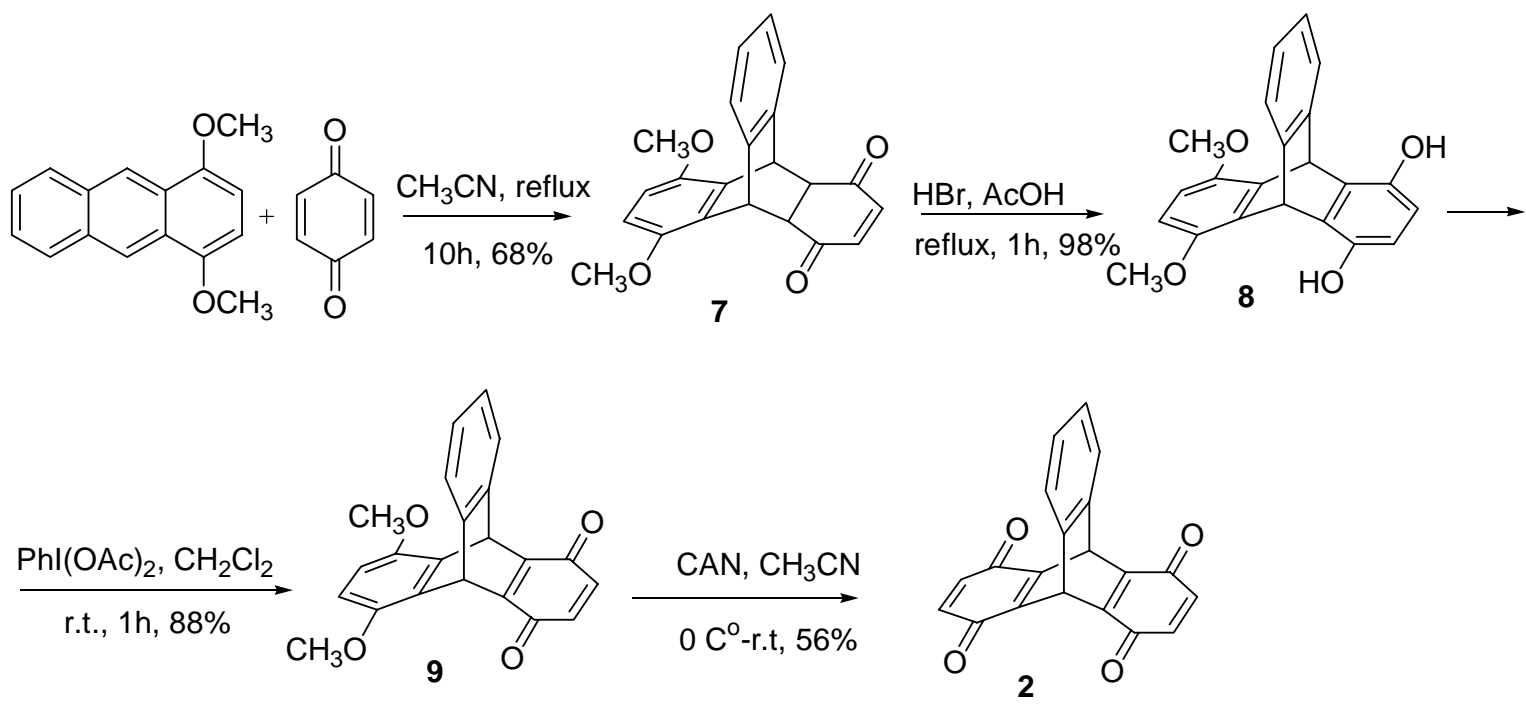

Scheme 3. Preparation of triptycene bis-quinone 2 . 
As was mentioned earlier, $\mathrm{PhI}(\mathrm{OAc})_{2}$ was found to be very effective for the oxidation of hydroquinone 8 to quinone 9. The use of a more conventional oxidant, like potassium bromate, also gave the desired 9 in $60 \%$ yield, along with $15 \%$ of bis-quinone 2 and $10 \%$ of the bromo derivative 10, thus complicating the reaction (Scheme 4).

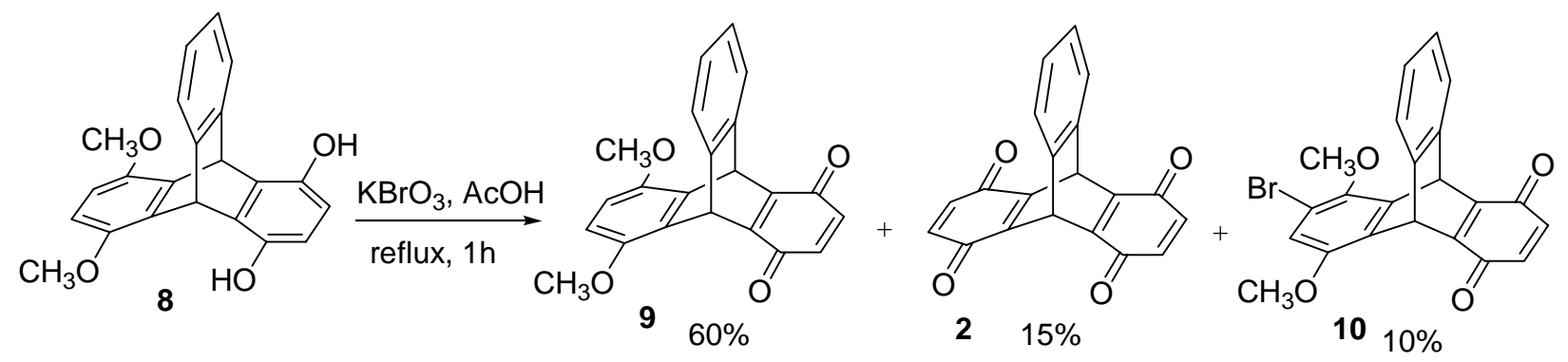

Scheme 4. Alternative preparation of 2.

In the next step bis-quinone 2 was converted under Thiele-Winter conditions to a mixture (1:1 estimated by ${ }^{1} \mathrm{H}-\mathrm{NMR}$ spectroscopy) of the two possible hexaacetoxy triptycene isomers $\mathbf{1 1}$. Acid hydrolysis under various conditions did not lead to hexahydroxy isomers 12, as complex mixtures of partially acetoxylated compounds were always isolated. In contrast, hydrolysis under basic conditions afforded 2-hydroxy-1,4-anthraquinone $\mathbf{1 4}$ as the only isolable product (Scheme 5). It is possible that $\mathbf{1 1}$ is converted to dihydroxy bis-quinone isomers $\mathbf{1 3}$, as in a typical reaction for the preparation of hydroxy quinones from 1,2,4-triacetoxybenzenes. ${ }^{12}$ Bis-quinone $\mathbf{1 3}$ affords 14 through a retro Diels-Alder reaction. This tendency of triptycene quinones to undergo retro Diels-Alder reactions under basic conditions has also been observed with other triptycene quinonic derivatives. ${ }^{16}$

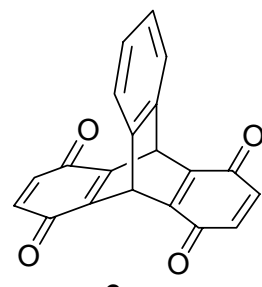

2

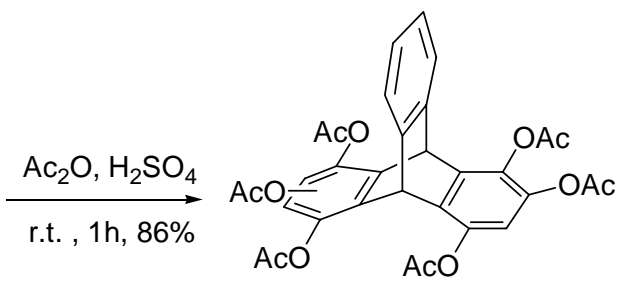

11

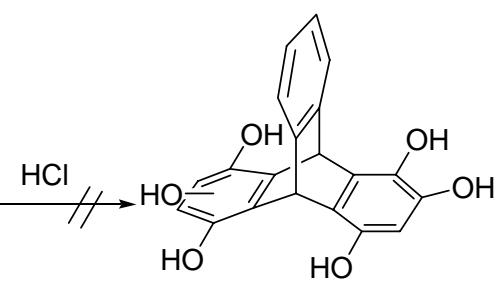

12

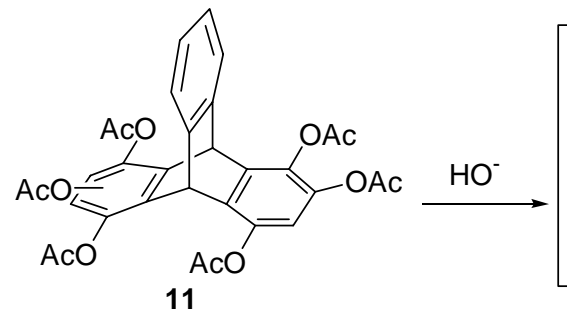

11

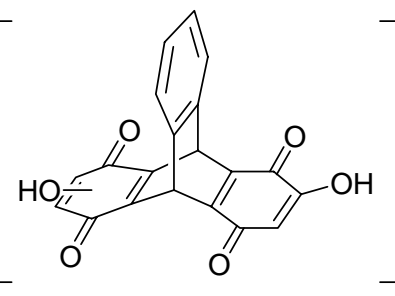

13<smiles>Cc1cc2ccccc2cc1C(=O)C(C)(C)O</smiles>

14 
Scheme 5. Unsuccessful attempts for the preparation of dihydroxy bis-quinones 13.

In order to confirm the formation of 14, this hydroxy quinone was prepared by an independent method: available 1,4-dimethoxyanthracene was oxidatively demethylated to 1,4anthraquinone, which in turn was transformed to 1,2,4-triacetoxyanthracene 14a which was hydrolyzed to 14 (Scheme 6).<smiles>COc1ccc(OC)c2cc3ccccc3cc12</smiles>

Scheme 6. Independent route to 2-hydroxy-1,4-anthraquinone 14.

Finally, the acetoxy groups of $\mathbf{1 1}$ were smoothly removed by $\mathrm{LiAlH}_{4}$ to afford a reasonable yield of hexahydroxytriptycene isomers 12. This mixture was converted in a tandem oxidationaryliodination reaction to the corresponding mixture of bis-ylide isomers 15 using four equivalents of $\mathrm{PhI}(\mathrm{OAc})_{2}$. This mixture was subjected to thermal decomposition in refluxing acetonitrile and the target molecule triptycene bis-cyclopentenedione $\mathbf{1 6}$ was isolated in $7 \%$ yield (Scheme 7).

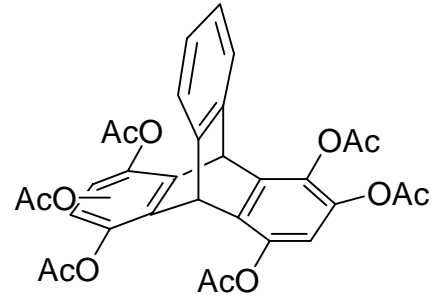

11

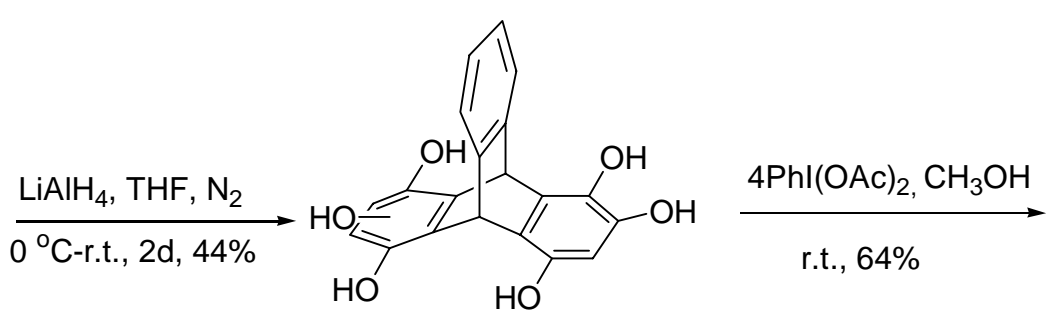

12

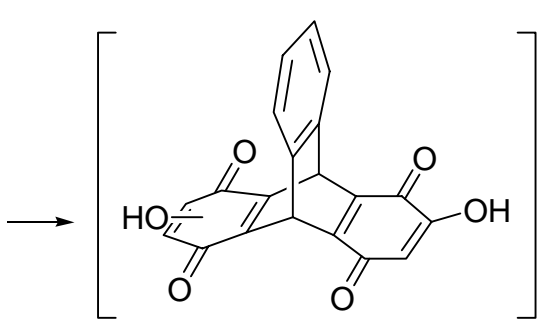

13

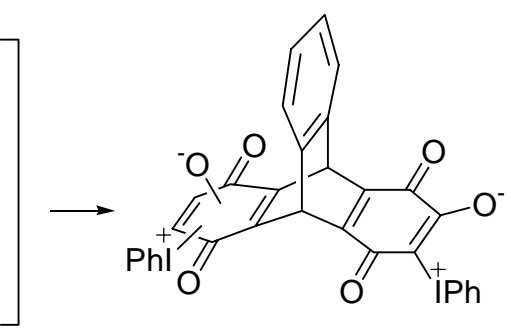

15

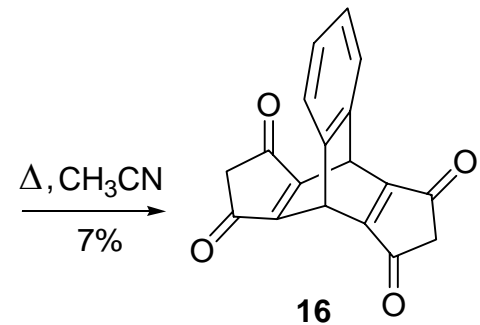

16

Scheme 7. Synthesis of triptycene bis-cyclopentenedione $\mathbf{1 6 .}$ 
Triptycene bis-cyclopentenedione $\mathbf{1 6}$ exists in solution in its tetraketo form, analogously to triptycene cyclopentenedione $17 .{ }^{13}$ The two compounds exhibit similar spectroscopic ${ }^{1} \mathrm{H}-\mathrm{NMR}$ and ${ }^{13} \mathrm{C}-\mathrm{NMR}$ data, the main difference being the anisotropy of the protons of the methylene groups in 16 (Figure 2).

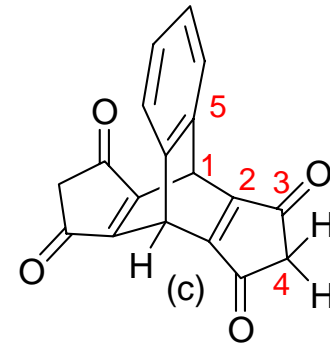

16 (a) $d, 1 \mathrm{H}, 3.16, \mathrm{~J}=21 \mathrm{~Hz}$

(b) $\mathrm{d}, 1 \mathrm{H}, 3.08, \mathrm{~J}=21 \mathrm{~Hz}$

(c) $\mathrm{s}, 2 \mathrm{H}, 5.70$

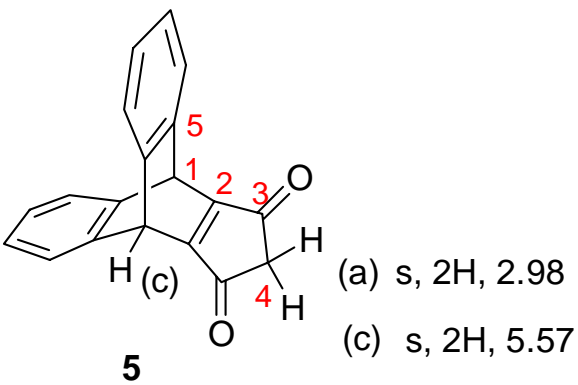

$\mathrm{C}_{1} 47.0 \quad \mathrm{C}_{2} 171.7 \quad \mathrm{C}_{3} 192.6$

$C_{4} 44.9 \quad C_{5} 143.3$

Figure 2. ${ }^{1} \mathrm{H}$ NMR and ${ }^{13} \mathrm{C}$ NMR data for triptycene bis- and mono-cyclopentenediones, 16 and $\mathbf{5}$.

We believe the reaction pathway to be essentially the same as that proposed for the thermal decomposition of aryliodonium ylides of 2-hydroxy-1,4-benzoquinones: ${ }^{17}$ bisketene $\mathbf{1 8}$ is produced by Wolff rearrangement of bis-carbene 17 resulting from extrusion of PhI.
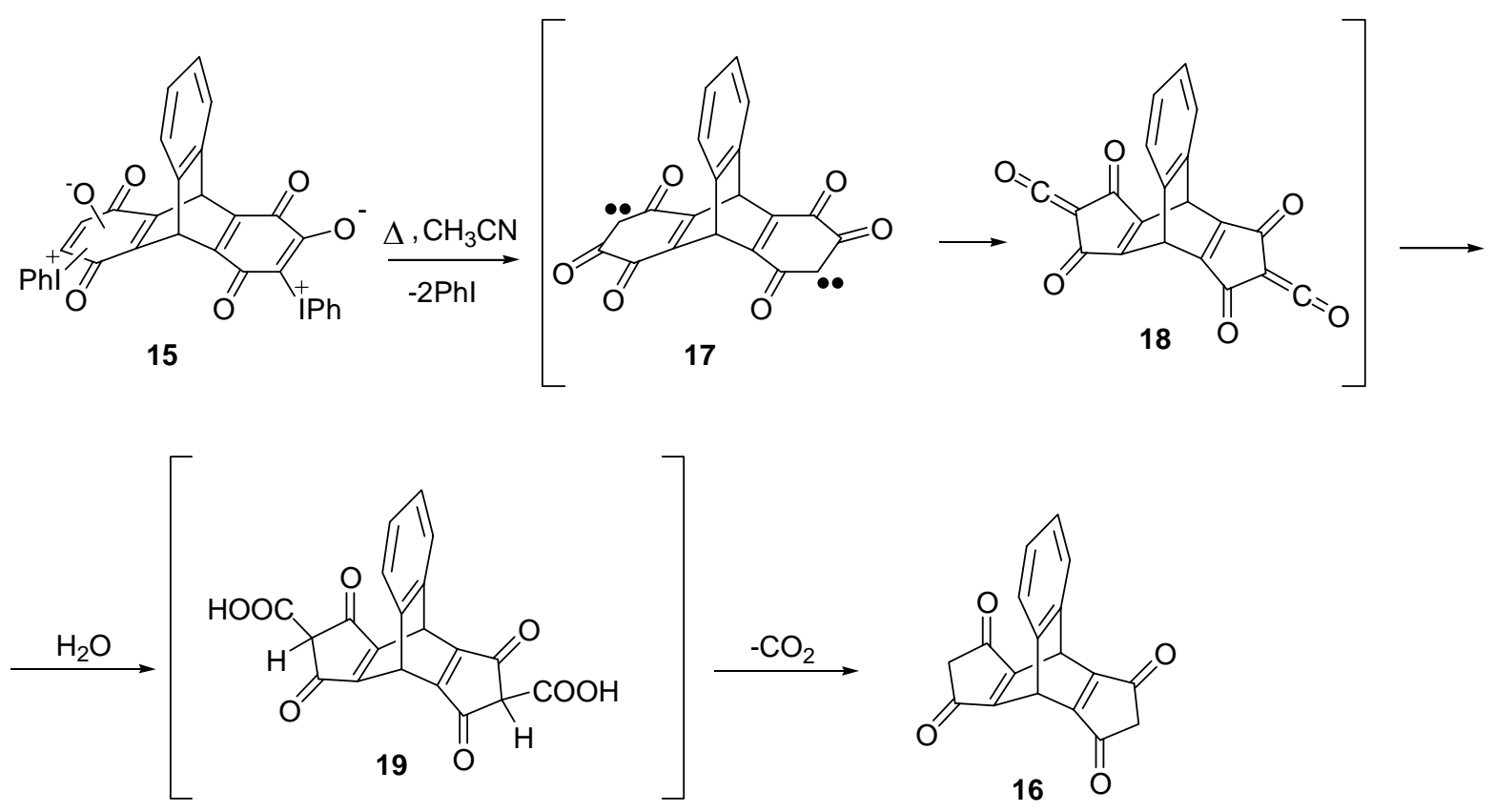

Scheme 8. Proposed reaction pathway for the preparation of $\mathbf{1 6 .}$ 
Highly reactive 18 undergoes hydrolysis with water present in the solvent and the resulting acid 19 decarboxylates to the desired triptycene bis-cyclopentenedione 16 (Scheme 8). This reaction pathway leads also to the preparation of $\mathbf{5}$ from the thermal degradation of the corresponding mono ylide. The formation of the intermediate ketene is supported by its trapping with methanol to form the corresponding ester. ${ }^{13}$

In conclusion we presented a reaction sequence for the preparation of triptycene biscyclopentenedione 16 based on hydroxyquinone-ylide formation chemistry. This compound, as well as its precursors, might serve as building blocks for the construction of polycyclic structures bearing the triptycene moiety.

\section{Experimental Section}

General Procedures. Melting points were determined on a Stuart Scientific Melting Point Apparatus SMP3 (230 Volts) and are uncorrected. ${ }^{1} \mathrm{H}-\mathrm{NMR}$ and ${ }^{13} \mathrm{C}-\mathrm{NMR}$ spectra were recorded with a Bruker AM $300\left(300 \mathrm{MHz}\right.$ and $75 \mathrm{MHz}$ for ${ }^{1} \mathrm{H}$ and ${ }^{13} \mathrm{C}$, respectively) in ca $5 \%$ solution of $\mathrm{CDCl}_{3}$ using $\mathrm{Me}_{4} \mathrm{Si}$ as the internal standard. Mass spectra were recorded with a spectrometer VG-250 in 70eV, ESI. Elemental analyses were carried out in a Perkin-Elmer 2400-II elemental analyst.

5,8-Dimethoxy-4a,9,9a,10-tetrahydro-9,10-[1,2]benzenoanthracene-1,4-dione, (7). To a solution of 1,4-dimethoxy-anthracene (2.26 g, $9.5 \mathrm{mmol}$ ) in $\mathrm{CH}_{3} \mathrm{CN}$ (40 mL) 1,4-benzoquinone $(4.2 \mathrm{~g}, 38.8 \mathrm{mmol})$ was added and the mixture was refluxed for $10 \mathrm{~h}$. After cooling, the yellowgreen precipitate formed was filtered and dried in a desiccator for $24 \mathrm{~h}$ to afford 7 (2.23 g, 68\%), mp $220{ }^{\circ} \mathrm{C}$ dec. ${ }^{1} \mathrm{H}-\mathrm{NMR} \delta 2.17(\mathrm{~s}, 2 \mathrm{H}), 3.80(\mathrm{~s}, 6 \mathrm{H}), 6.54(\mathrm{~s}, 2 \mathrm{H}), 6.58(\mathrm{~s}, 2 \mathrm{H}), 7.00-7.11(\mathrm{~m}$, 2H), 7.42-7.51 (m, 2H). MS (70 eV); m/z (\%): 347 (M+1, 100), 239 (77), 224 (70), 208 (31), 180 (48), 152 (68). Anal. Calcd for $\mathrm{C}_{22} \mathrm{H}_{18} \mathrm{O}_{4}$ : C, 76.28\%; H, 5.24\%. Found C, 76.01\%; H, $5.50 \%$.

5,8-Dimethoxy-9,10-dihydro-9,10-[1,2]benzenoanthracene-1,4-diol, (8). A suspension of 5,8dimethoxy-4a,9,9a,10-tetrahydro-9,10-[1,2] benzenoanthracene-1,4-dione, 7 (0.75 g, $2.16 \mathrm{mmol})$ in $\mathrm{CH}_{3} \mathrm{COOH}(50 \mathrm{~mL})$ was refluxed until the solid was completely dissolved (20-30 min). Hydrobromic acid (48\% solution, 20 drops) was added and the resulting mixture was poured onto water $(10 \mathrm{~mL})$. The white precipitate formed was filtered and dried in a desiccator for $24 \mathrm{~h}$ to yield $3(0.74 \mathrm{~g}, 98 \%), \mathrm{mp}>200{ }^{\circ} \mathrm{C}$ dec. ${ }^{1} \mathrm{H}-\mathrm{NMR}\left(\mathrm{CDCl}_{3}+\mathrm{DMSO}_{-} \mathrm{d}_{6}\right) \delta 3.80(\mathrm{~s}, 6 \mathrm{H}), 6.27(\mathrm{~s}$, 2H), $6.34(\mathrm{~s}, 2 \mathrm{H}), 6.55(\mathrm{~s}, 2 \mathrm{H}), 6.96-7.01(\mathrm{~m}, 2 \mathrm{H}), 7.35-7.42(\mathrm{~m}, 2 \mathrm{H}) . \mathrm{MS}(70 \mathrm{eV}) ; \mathrm{m} / \mathrm{z}(\%): 348$ (M+2, 100), 330 (36), 316 (94), 298 (34), 284. Anal. Calcd for $\mathrm{C}_{22} \mathrm{H}_{18} \mathrm{O}_{4}$ : C, 76.28\%; H, 5.24\%; Found: C, 76.68\%; H, 4.99\%.

5,8-Dimethoxy-9,10-dihydro-9,10-[1,2]benzenoanthracene-1,4-dione, (9). To a solution of 5,8-dimethoxy-9,10-dihydro-9,10-[1,2]benzenoanthracene-1,4-diol, 8 (0.243 g, $0.70 \mathrm{mmol})$ in 
$\mathrm{CH}_{2} \mathrm{Cl}_{2}(8 \mathrm{~mL})$ a solution of (diacetoxyiodo)benzene $(0.237 \mathrm{~g}, 0.73 \mathrm{mmol})$ in $\mathrm{CH}_{2} \mathrm{Cl}_{2}(8 \mathrm{~mL})$ was added with stirring at room temperature. Stirring was continued for one h. The solution was concentrated to dryness and purified by column chromatography (silica gel) using a mixture of hexanes - ethyl acetate (5:1) as eluant to afford $0.21 \mathrm{~g}$ of 9 (yield 88\%), mp $271-272{ }^{\circ} \mathrm{C} .{ }^{1} \mathrm{H}$ NMR $\delta 3.81(\mathrm{~s}, 6 \mathrm{H}), 6.24(\mathrm{~s}, 2 \mathrm{H}), 6.55(\mathrm{~s}, 2 \mathrm{H}), 6.59(\mathrm{~s}, 2 \mathrm{H}), 7.00-7.05(\mathrm{~m}, 2 \mathrm{H}), 7.42-7.50(\mathrm{~m}$, 2H). ${ }^{13} \mathrm{C}-\mathrm{NMR} \delta 41.2,56.3,109.3,124.5,125.2,133.4,135.2,144.1,149.5,152.7,183.5(\mathrm{C}=\mathrm{O})$. MS (70 eV); m/z (\%): $344\left(\mathrm{M}^{+}, 100\right), 330$ (40), $286(25), 176$. Anal. Calcd for $\mathrm{C}_{22} \mathrm{H}_{16} \mathrm{O}_{4}: \mathrm{C}$, $76.73 \%$; H 4.68\%. Found C, 76.41\%; H, 4.67\%.

9,10-Dihydro-9,10- [1,2]benzenoanthracene-1,4,5,8-tetrone, (2). To a magnetically stirred solution of 5,8-dimethoxy-9,10-dihydro-9,10-[1,2]benzenoanthracene-1,4-dione, 9 (0.73 g, 2.1 $\mathrm{mmol})$ in $\mathrm{CH}_{3} \mathrm{CN}(70 \mathrm{~mL})$ at $0{ }^{\circ} \mathrm{C}$ a solution of ceric ammonium nitrate, $\mathrm{CAN}, \quad(3.4 \mathrm{~g}, 6.2$ $\mathrm{mmol})$ in $\mathrm{H}_{2} \mathrm{O}(60 \mathrm{~mL})$ was added drop wise. Stirring was continued for two hours at room temperature, excess $\mathrm{CH}_{3} \mathrm{CN}$ was removed in the rotary evaporator and the resulting solution was extracted with $\mathrm{CH}_{2} \mathrm{Cl}_{2}(3 \mathrm{x} 40 \mathrm{~mL})$. The solution was concentrated to dryness and purified by column chromatography (silica gel) using a mixture of hexanes-ethyl acetate (5:1) as eluant to afford $0.38 \mathrm{~g}$ of 2 (yield 57\%), yellow crystals, mp $220{ }^{\circ} \mathrm{C}$ dec. ${ }^{1} \mathrm{H}-\mathrm{NMR} \delta 6.18$ (s, 2H), 6.65 (s, 4H), 7.07-7.10 (m, 4H), 7.47-7.50 (m, 4H) . ${ }^{13} \mathrm{C}-\mathrm{NMR} \delta 42.2,125.5,126.0,135.5,151.6,182.2$ $(\mathrm{C}=\mathrm{O}) . \mathrm{MS}(70 \mathrm{eV}) ; \mathrm{m} / \mathrm{z}(\%): 314\left(\mathrm{M}^{+}, 100\right), 286$ (15), 258 (25), 232 (60), 208 (75) 176 (24). Anal. Calcd for $\mathrm{C}_{20} \mathrm{H}_{10} \mathrm{O}_{4}$ : C, 76.43\%; H, 3.20\%. Found C, 76.30\%; H, 3.00\%.

Oxidation of $\mathbf{8}$ with $\mathbf{K B r O}_{3}$. A solution of 5,8-dimethoxy-9, 10-dihydro-9, 10[1,2] benzenoanthracene-1,4-diol, $8(0.3 \mathrm{~g}, 0.96 \mathrm{mmol})$ in $\mathrm{CH}_{3} \mathrm{COOH}(20 \mathrm{~mL})$ was refluxed till the hydroquinone was dissolved. A solution of $\mathrm{KBrO}_{3}(1.6 \mathrm{~g}, 9.4 \mathrm{mmol})$ in $\mathrm{H}_{2} \mathrm{O}(10 \mathrm{~mL})$ was added using a dropping funnel, followed by the addition of another $10 \mathrm{~mL}$ of $\mathrm{H}_{2} \mathrm{O}$ and reflux was continued for $10 \mathrm{~min}$. After cooling at $\mathrm{rt}$ the resulting solid was filtered and subjected to column chromatography (silica gel, hexanes-ethyl acetate, 5:1) to afford in order of eluance a) Dimethoxyquinone, 9 (0.17 g, 60\% yield) b) 6-Bromo-5,8-dimethoxy-9,10-dihydro-9,10[1,2]benzenoanthracene-1,4-dione, (10), (0.037 g, yield 10\%). ${ }^{1} \mathrm{H}$ NMR $\delta 3.81(\mathrm{~s}, 3 \mathrm{H}), 3.85$ (s, $3 \mathrm{H}), 6.15(\mathrm{~s}, 1 \mathrm{H}), 6.19(\mathrm{~s}, 1 \mathrm{H}), 6.62(\mathrm{~s}, 2 \mathrm{H}), 6.78(\mathrm{~s}, 1 \mathrm{H}), 6.92-7.08(\mathrm{~m}, 2 \mathrm{H}), 7.42-7.50(\mathrm{~m}, 2 \mathrm{H})$. ${ }^{13} \mathrm{C}$ NMR $\delta$ 41.1, 42.65, 56.20, 62.20, 113.5, 124.6, 124.7, 135.3,135.4, 143.3, 151.6, 183.2 $(\mathrm{C}=\mathrm{O})$ and $\mathrm{c})$ diquinone $2(0.046 \mathrm{~g}, 15 \%$ yield $)$.

Thiele-Winter preparation of 1,2,4,5,6,(7),8-hexacetoxy-9,10-dihydro-9,10-[1,2] benzenoanthracenes (or 1,2,4,5,6,(7),8-hexacetoxytriptycenes), (11). To a magnetically stirred solution of 9,10-dihydro-9,10- [1,2]benzenoanthracene-1,4,5,8-tetrone, 2 (0.38 g, $1.2 \mathrm{mmol})$ in acetic anhydride $(65 \mathrm{~mL})$ a catalytic amount $(0.8 \mathrm{~mL})$ of $\mathrm{H}_{2} \mathrm{SO}_{4}$ was added drop wise and stirring was continued for $24 \mathrm{~h}$. The mixture was poured onto ice-water $(200 \mathrm{~mL})$, stirring was continued for one hour and the resulting solid was filtered, washed repeatedly with water and dried in a desiccator to afford 11 as off-white solid (0.64 g, yield 86\%), mp 194-198 ${ }^{\circ} \mathrm{C} \mathrm{dec}$. The 1:1 ratio of the two isomers (11a and 11b) was estimated by integration of the peaks of the bridge protons in ${ }^{1} \mathrm{H}$ NMR (Figure 3). 

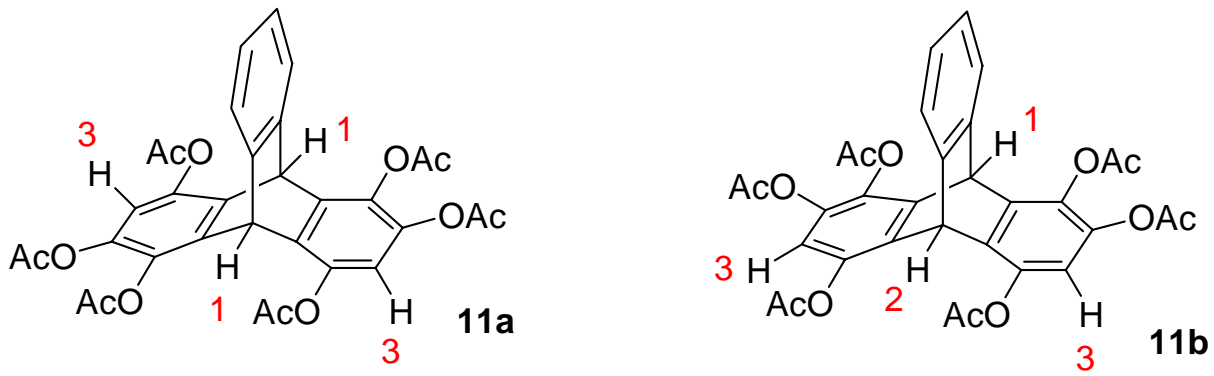

Figure 3

Both bridge protons $(\mathrm{H}-1)$ in 11a appear as a singlet at $5.50 \delta$, whereas in 11b $\mathrm{H}-1$ gives a singlet at $5.53 \delta$ and $\mathrm{H}-2$ a singlet at $5.45 \delta$. H-3 appears as two singlets for both isomers at 6.78 and $6.79 \delta$. The methyl groups give broad singlets at 2.23 and $2.40(1: 2) \delta$ and the aromatic protons resonate at 7.01-7.06 (m) and 7.31-7.36 (m). MS (70 eV); m/z (\%): $602\left(\mathrm{M}^{+}, 33\right), 560$ (37), 518 (25), 207 (50), 135 (100).

Attempts for hydrolysis of 11. All attempts of acid-hydrolysis of $\mathbf{1 1}$ to the corresponding hexahydroxy derivative 12 failed. In all cases $\left(\mathrm{HCl}\right.$ acid of different concentration, $\mathrm{CH}_{3} \mathrm{OH}$ as solvent, prolonged periods of reaction at room temperature, heating etc.) complex mixtures of partially hydrolyzed products were isolated. Sometimes even the presence of methoxy groups (probably from the solvent) were detected by ${ }^{1} \mathrm{H}-\mathrm{NMR}$ spectroscopy in the products.

Complicated mixtures of products were also the results of hydrolysis with aqueous $\mathrm{NaOH}$. In this case the only isolable product (after column chromatography in 10-15\% yields) was 2hydroxy-1,4-anthraquinone $14, \mathrm{mp} 238-241{ }^{\circ} \mathrm{C}$, lit. ${ }^{18} \mathrm{mp} 243{ }^{\circ} \mathrm{C} .{ }^{1} \mathrm{H}$ NMR $\delta 6.48(\mathrm{~s}, 1 \mathrm{H}), 7.70$ (m, 2H), 8.05 (m, 2H), 8.65 (s, 1H), 8.67 (s, 1H), 8.95 (s, br, 1H, OH).

Alternative preparation of 2-hydroxy-1,4-anthraquinone (14). To a magnetically-stirred solution of 1,4-dimethoxyanthracene $(0.48 \mathrm{~g}, 2 \mathrm{mmol})$ in $\mathrm{CH}_{3} \mathrm{CN}(50 \mathrm{~mL})$ at $0{ }^{\circ} \mathrm{C}$ a solution of CAN (3.3 g, $6 \mathrm{mmol})$ in water $(45 \mathrm{~mL})$ was added, the ice bath was removed and stirring was continued for 2 hours. Excess $\mathrm{CH}_{3} \mathrm{CN}$ was removed in the rotary evaporator and the resulting suspension was extracted with $\mathrm{CH}_{2} \mathrm{Cl}_{2}(3 \times 50 \mathrm{~mL})$. The solvent was evaporated to dryness and the residue was chromatographed on column (silica gel, hexanes-ethylacetate 5:1) to afford $0.264 \mathrm{~g}, 63 \%$ yield, of 1,4-anthraquinone, mp $214-217^{\circ} \mathrm{C}$ dec, lit. ${ }^{19} 219-223{ }^{\circ} \mathrm{C}$ dec. ${ }^{1} \mathrm{H}-\mathrm{NMR}$ $\delta 7.07(\mathrm{~s}, 2 \mathrm{H}), 7.68-7.71(\mathrm{~m}, 2 \mathrm{H}), 8.05-8.08(\mathrm{~m}, 2 \mathrm{H}), 8.61(\mathrm{~s}, 2 \mathrm{H}) . \mathrm{MS}(70 \mathrm{eV}) ; \mathrm{m} / \mathrm{z}(\%): 208$ $\left(\mathrm{M}^{+}, 60\right), 180$ (75), 153 (95), 127 (100), 76 (66). To a magnetically-stirred solution of 1,4anthraquinone $(0.26 \mathrm{~g}, 1.25 \mathrm{mmol})$ in acetic anhydride $(40 \mathrm{~mL})$ a catalytic amount $(0.7 \mathrm{~mL})$ of $\mathrm{H}_{2} \mathrm{SO}_{4}$ was added dropwise and stirring was continued for $30 \mathrm{~min}$. The mixture was poured onto ice-water $(100 \mathrm{~mL})$, stirring was continued for an additional hour and the resulting solid was filtered, washed repeatedly with water and dried in a desiccator to afford 1,2,4triacetoxyanthracene (14a) $(0.185 \mathrm{~g}, 42 \%$ yield $), \mathrm{mp} 188-190{ }^{\circ} \mathrm{C}$, lit. ${ }^{18} \mathrm{mp} 191{ }^{\circ} \mathrm{C} .{ }^{1} \mathrm{H}-\mathrm{NMR} \delta$ $2.22(\mathrm{~s}, 3 \mathrm{H}), 2.46(\mathrm{~s}, 3 \mathrm{H}), 2.67(\mathrm{~s}, 3 \mathrm{H}), 6.88(\mathrm{~s}, 1 \mathrm{H}), 7.09-7.13(\mathrm{~m}, 2 \mathrm{H}), 7.41-7.45(\mathrm{~m}, 2 \mathrm{H}), 8.26$ $(\mathrm{s}, 1 \mathrm{H})$. To a magnetically-stirred solution of $15(0.04 \mathrm{gr}, 0.12 \mathrm{mmol})$ in $\mathrm{CH}_{3} \mathrm{OH}(5 \mathrm{~mL})$ a 
solution of $20 \% \mathrm{NaOH}(1 \mathrm{~mL})$ was added and stirring was continued for 2 hours. The resulting solution was acidified with $20 \% \mathrm{HCl}$ acid, poured onto water $(10 \mathrm{~mL})$ and the precipitated solid was filtered and dried to afford 2-hydroxy-1,4-anthraquinone $14(0.015 \mathrm{~g}, 60 \%)$, in all respects identical to that isolated from the basic-hydrolysis of hexaacetoxytriptycenes 11.

Preparation of 1,2,4,5,6,(7),8-hexahydroxy-9,10-dihydro-9,10-[1,2]benzenoanthracenes (or 1,2,4,5,6,(7),8-hexahydroxytriptycenes), (12). A $100 \mathrm{~mL}$ three-necked flask, equipped with a reflux condenser and a pressure-equalizing dropping funnel, was charged with a suspension of $\mathrm{LiAlH}_{4}(0.33 \mathrm{~g}, 8.7 \mathrm{mmol})$ in anhydrous THF $(10 \mathrm{~mL})$ under Ar. A degassed solution of hexacetoxytriptycenes $11(0.6 \mathrm{~g}, 1 \mathrm{mmol})$ in anhydrous THF $(20 \mathrm{~mL})$ was added from the dropping funnel at $0{ }^{\circ} \mathrm{C}$ with stirring, during a period of $30 \mathrm{~min}$. The cooling bath was removed, the reaction mixture was allowed to reach $\mathrm{rt}$ and finally it was refluxed for 6 hours. After cooling the resulting mixture was carefully poured onto ice- $\mathrm{H}_{2} \mathrm{SO}_{4}(10 \%, 30 \mathrm{~mL})$. The reaction flask was rinsed thoroughly with ether and the combined ether-THF suspension was filtered through a thick layer of celite. The organic solvents were removed with the rotary evaporator, the water suspension was extracted with ether $(5 \times 30 \mathrm{~mL})$ and dried with $\mathrm{Na}_{2} \mathrm{SO}_{4}$. Ether was removed to afford 1,2,4,5,6,(7),8-hexahydroxytriptycenes $12(0.15 \mathrm{~g}, 44 \%) \mathrm{mp}>300{ }^{\circ} \mathrm{C} .{ }^{1} \mathrm{H}$-NMR $\left(\mathrm{CDCl}_{3}+\mathrm{DMSO}_{-} \mathrm{d}_{6}\right) \delta$ both isomers give a complex set of singlets for bridge and aromatic protons (of the trihydroxy moieties) at 5.94, 6.02, 6.06, $6.08(4 \mathrm{H}$, total) , $6.9(\mathrm{~m}, 2 \mathrm{H}), 7.29(\mathrm{~m}$, 2H). MS (70 eV); m/z (\%): $350\left(\mathrm{M}^{+}, 37\right), 332$ (8), 224 (12), 210 (23), 196 (29) 155 (50), 126 (100). Anal. Calcd for $\mathrm{C}_{20} \mathrm{H}_{14} \mathrm{O}_{6}$ : C, 68.57\%; H, 4.03\%. Found C, 68.28\%; H, 4.40\%.

Preparation of 2,7-dioxido-3,6-di(phenyliodonio)-9,10-dihydro-9,10-[1,2]benzenoanthracene1,4,5,8-tetrone and 2,6-dioxido-3,7-di(phenyliodonio)-9,10-dihydro-9,10-[1,2]benzenoanthracene1,4,5,8-tetrone mixture (15). A solution of (diacetoxyiodo)benzene $(0.57 \mathrm{~g}, 1.76 \mathrm{mmol})$ in $\mathrm{CH}_{3} \mathrm{OH} \quad(8 \mathrm{~mL})$ was added dropwise to a magnetically-stirred solution of hexahydroxytriptycenes $12(0.15 \mathrm{~g}, 0.44 \mathrm{mmol})$ at $0{ }^{\circ} \mathrm{C}$. The ice-bath was removed and stirring was continued for one hour at room temperature. The orange precipitate was filtered, the methanolic filtrate was evaporated in vacuum, keeping the temperature as low as possible, and the oily remnant was triturated with ether to afford a second crop of the product. The combined solids were washed repeatedly with ether to afford $0.37 \mathrm{~g}$ (57\% yield) of $\mathbf{1 5}$ as a red-orange powder, mp $120-122{ }^{\circ} \mathrm{C}$ dec., kept all the time in the refrigerator. Anal. Calcd for $\mathrm{C}_{32} \mathrm{H}_{16} \mathrm{I}_{2} \mathrm{O}_{6}: \mathrm{C}$, $51.23 \%$; H, 2.15\%. Found C, 51.66\%; H, 1.91\%.

Triptycene bis-cyclopentenedione (16). A suspension of bis-ylide 15 (0.36 g, $0.48 \mathrm{mmol})$ in $\mathrm{CH}_{3} \mathrm{CN}$ (12 mL) was refluxed for $4 \mathrm{~h}$. The clear solution was evaporated to dryness and the residue was chromatographed on column (silica gel, hexanes-ethyl acetate 5:1 to 2:1) to afford, after iodobenzene extrusion, triptycene bis-cyclopentenedione $\mathbf{1 6}$ as yellowish crystals $(0.01 \mathrm{~g}$, 7\%), mp 106-108 ${ }^{\circ} \mathrm{C} .{ }^{1} \mathrm{H}-\mathrm{NMR} \delta 3.08(\mathrm{~d}, \mathrm{~J}=21 \mathrm{~Hz}, 1 \mathrm{H}), 3.16(\mathrm{~d}, \mathrm{~J}=21 \mathrm{~Hz}, 1 \mathrm{H}), 5.70(\mathrm{~s}, 2 \mathrm{H})$, 7.08-7.12 (m, 2H), 7.47-7.52 (m, 2H). ${ }^{13} \mathrm{C}-\mathrm{NMR} \delta 40.9,45.9,126.5,142.7,171.9,190.5$ MS (70 $\mathrm{eV}) ; \mathrm{m} / \mathrm{z}(\%): 289\left(\mathrm{M}-1^{+}, 7\right), 213$ (60), 149 (78), 126 (100). Anal. Calcd for $\mathrm{C}_{18} \mathrm{H}_{10} \mathrm{O}_{4}: \mathrm{C}$, $74.48 \%$; H 3.47\%. Found C, 74.92\%; H, 3.64\%. 


\section{References}

1. (a) Hashimoto, M.; Tagaki, H.; Yamamura, K. Tetrahedron Lett. 1999, 40, 6037. (b) Hashimoto, M.; Yamamura, K.; Yamane, J. Tetrahedron 2001, 51, 10253.

2. Norvez, S. J. Org. Chem. 1993, 58, 2414.

3. (a) Wiehe, A.; Senge, M. O.; Kurreck, H. Liebigs Ann./Recueil 1997, 1951. (b) Wiehe, A.; Senge, M. O.; Schäfer, A.; Speck, M.; Tannert, S.; Kurreck, H.; Röder, B. Tetrahedron, 2001, 51, 10089.

4. Scheib, S.; Cava, M. P.; Baldwin, J. W.; Metzer, R. M. J. Org. Chem. 1998, 63, 1198.

5. Yang, J.-S.; Swager, T. M. J. Am. Chem. Soc. 1998, 120, 11864.

6. Yang, J.-S.; Lee, C.-C.; Yau, S.-L.; Chang, C.-C.; Lee, C.-C.; Leu, J.-M. J. Org. Chem. 2000, 65, 871.

7. Yang, J.-S.; Lin,C.-S; Hwang, C.-S. Org. Lett. 2001, 3, 889.

8. Yang, J.-S.; Liu, C.-P.; Lee, G.-H Tetrahedron Lett. 2001, 41, 7911.

9. Perchellet, E. M.; Magill, M. J.; Huang, X.; Brantis, C. E.; Hua, D. H.; Perchellet, J.-P. AntiCancer Drugs 1999, 10, 749.

10. Xanthopoulou, N.J.; Kourounakis, A. P.; Spyroudis, S.; Kourounakis, P.N. Eur. J. Med. Chem., accepted for publication.

11. Hua, D.H.; Tamura, M.; Huang, X.; Stephany, H, A.; Helfrich, B.A.; Perchellet, E.M., Sperfslage, B. J.; Perchellet, J-P.; Jiang, S.; Kyle, D. E.; Chiang, P.K. J. Org. Chem. 2002, 67, 2907.

12. Spyroudis, S. Molecules 2000, 5, 1291.

13. Spyroudis, S.; Xanthopoulou, N. J. Org. Chem. 2002, 67, 4612.

14. Iwamura, H.; Makino, K. J. Chem. Soc., Chem. Commun. 1978, 720.

15. Criswell, T. R.; Klanderman, B. H. J. Org. Chem. 1974, 39, 770.

16. Xanthopoulou, N. Ph. D. Thesis to be submitted at the University of Thessaloniki.

17. Papoutsis, I.; Spyroudis, S.; Varvoglis, A. Tetrahedron Lett. 1994, 35, 8449.

18. Fieser, L. J. Am. Chem. Soc. 1928, 50, 465.

19. Cava, M., D.; Deava, A. A.; Muth, K. J. Am. Chem. Soc. 1959, 81, 6458. 